\title{
ALLELOPATHIC EFFECTS OF COMMON BRACKEN (Pteridium aquilinum (L.) Kuhn) ON GERMINATION AND GROWTH OF ECONOMICALLY IMPORTANT WEEDS
}

\author{
Yerly D. Mira ${ }^{1 \mathrm{a} *}$, Luis A. Ramírez ${ }^{1 \mathrm{~b}}$, Luisa F. Londoño ${ }^{1 \mathrm{c}}$, and Darío A. Castañeda ${ }^{2}$ \\ ${ }^{1 a}$ Facultad de Ciencias Agrarias, Politécnico Colombiano Jaime Isaza Cadavid, PC: 050021, Medellín, \\ Colombia \\ ORCID: https://orcid.org/0000-0002-4655-141X. \\ ${ }^{1 b}$ Facultad de Ciencias Agrarias, Politécnico Colombiano Jaime Isaza Cadavid, PC: 050021, Medellín, \\ Colombia. \\ 1c Facultad de Ciencias Agrarias, Politécnico Colombiano Jaime Isaza Cadavid, PC: 050021, Medellín, \\ Colombia. \\ ${ }^{2}$ Departamento de Ciencias Agronómicas, Facultad de Ciencias Agrarias, Universidad Nacional de \\ Colombia, PC: 050034, Medellín, Colombia \\ ORCID: https://orcid.org/0000-0002-2693-371X \\ * Corresponding author E-mail: yerlymira@elpoli.edu.co
}

\begin{abstract}
Pteridium aquilinum (L.) Kuhn is a cosmopolitan plant with great competitive abilities, including allelopathy. The search for plants with negative allelopathic effects on other undesirable plants has led to the discovery of new useful substances for weed control. The objective of this research was to evaluate the allelopathic effect of $P$. aquilinum on seed germination and growth of four economically important weeds: Bidens pilosa L., Brachiaria decumbens Stapf, Emilia sonchifolia (L.) DC. ex DC and Rumex crispus L. Two experiments were conducted under laboratory and greenhouse conditions using extracts and dried plant residues of $P$. aquilinum, respectively. For the first experiment, extracts of bracken were obtained using four different solvents (hexane, dichloromethane, ethyl acetate, and methanol) and applied to the test seeds; germination rates were determined. For the second experiment, dry residues of bracken were applied to the soil at concentrations of 2,5 , and $10 \%$ and their effect on weed growth variables was determined; a control treatment (no appliacation) was also included. In addition, the presence of some chemical groups associated with each type of extract was qualitatively detected. The extracts inhibited seed germination by $52-97 \%$ in all the studied species. Dichloromethane and methanol were the most efficient solvents, while E. sonchifolia was the most sensitive species. The dry residues of bracken reduced germination by $18-44 \%$ of all the weeds, as well as root length of Bidens pilosa $(-30 \%)$ and Brachiaria decumbens $(-82 \%)$. The phytochemical analysis showed the presence of flavonoids, tannins, and polyphenols in the extracts. These results suggest that $P$. aquilinum can be a good alternative for the biocontrol of the weeds under study and provide knowledge for the development of bioherbicides.
\end{abstract}

Keywords: allelochemicals, phytotoxicity, weed biocontrol, bioherbicides, weed management. 


\section{INTRODUCTION}

Pteridium aquilinum (L.) Kuhn, also known as common bracken, is a species belonging to the Dennstaedtiaceae family. It is widely distributed worldwide and considered as one of the five most abundant plants on earth, being very difficult to control (Gil et al., 2012; Bardon et al., 2018). P. aquilinum presents tolerance to a wide range of environmental and edaphic conditions, invasively colonizing different types of environments such as grasslands, agricultural and forest areas, degraded or altered areas, and particularly open places with a high incidence of light (Lovato et al., 2016). The ecological attributes of this species include extensive rhizome system, high spore production, high resistance to fire and drought, fast and lush growth, and allelopathic properties (Butnariu et al., 2015).

According to Rice (1984), allelopathy is defined as any direct or indirect effect caused by a plant (donor) on another or other plants (recipients) through the production and release of chemical compounds into the environment. These compounds are known as allelochemicals and can both stimulate and inhibit germination and/or growth of recipient species (Li et al., 2021). Some research has shown the allelopathic potential of $P$. aquilinum to inhibit the growth and development of various cultivated and uncultivated plants (Wang et al., 2011; Bracho and Arnaude, 2012). However, given the diverse chemical nature of plants, the allelochemicals released can lead to different mechanisms of action in recipient plants, and thus an allelopathic effect may or may not be observed in a given species (Cheng and Cheng, 2015). In this regard, a study conducted under field conditions in the tropics revealed that $P$. aquilinum hindered the establishment of several pioneer plant species, while it also favored seed germination of late-successional plant species (Ssali et al.,2019). Thus, it seems that biological responses depend on several factors, including the type of allelochemical involved, type of donor plant and recipient plant, phenological state of the species, concentration tested, the organ of the plant where the compounds are produced, environmental conditions, soil microbiological activity, among others (Eichenberg et al., 2014).

In general, allelochemicals are grouped into three main classes: phenols, terpenoids, and compounds with a nitrogen atom. In terms of allelopathic activity, simple phenols, flavonoids, terpenoids, coumarins, and quinones are among the most commonly reported chemical groups (Macías et al., 2019). P. aquilinum contains a large number of chemically heterogeneous compounds with varied biological activity, some of which have been identified as dihydrofolic acid, $p$-coumaric acid, glycosides, cyanogens, and thiaminases (Leitolis et al., 2017). Although some compounds are recognized as the main determinants of the toxicity exerted by common bracken, the impact of many others is still unknown (Gil et al., 2012). Identifying these compounds and their possible negative effects on one or more plants is essential to determine their potential in the synthesis of bioherbicides, which would allow discovering new mechanisms of action for weed control and in turn mitigate herbicide resistance (Trezzi et al., 2016). Currently, there are 502 cases of herbicideresistant weeds (263 species) reported in 94 crops in 71 countries. In addition, resistance is recorded in 21 of the 31 known sites of action (Heap, 2021).

The integrated weed management system (IWMS) in agroecosystems aims at the diversification and combination of alternative control strategies in order to reduce dependence on the use of conventional herbicides (Scavo \& Mauromicale, 2020). In this sense, the allelopathic activity of $P$. aquilinum could represent a promising alternative for weed management, particulary for species that are difficult to control, have great economic importance, and/or have recorded resistance or tolerance to herbicides. In this regard, Bidens pilosa (Asteraceae) is recognized as a highly invasive weed present in at least 31 different crops in more than 40 countries around the world (Chauhan et al., 2019), and identified as glyphosate and paraquat resistant in Mexico and atrazine resistant in Brazil (Heap, 2021). Brachiaria decumbens (Poaceae) is often used as a cover crop and/or in integrated crop-livestock systems. However, it is considered an undesirable species in several perennial crops due to its strong competition capacity and difficulty to control (Oliveira et al., 2015). E. sonchifolia (Asteraceae) is an infesting plant in crops of various altitudinal ranges, which is often classified as moderately aggressive but with great ease and establishment capacity due to its potential for seed production (Grace et al., 2020). R. crispus (Polygonaceae) is considered as a highly problematic weed in several tropical countries, particularly in grasslands and prairie crops (Hujerová et al., 2017). In Argentina, it was reported as glyphosate resistant (Riley et al., 2011).

The objectives of this study were to: determine the effect of different extracts of $P$. aquilinum on the germination rate of four weeds (Bidens pilosa, Brachiaira decumbens, E. sonchifolia and R. crispus); and 2) evaluate the effect of soil applications of dry residues of $P$. aquilinum on the germination and initial growth of the four weeds. To do so, two experiments were conducted under laboratory 
and greenhouse conditions, respectively. In addition, a qualitative detection was carried out to determine the presence/absence of some chemical groups associated with the extracts.

\section{MATERIALS AND METHODS}

\section{Experimental setup}

During the second half of 2019 and the first half of 2020, two experiments were carried out to determine the allelopathic effect of common bracken on four economically important weeds in agriculture. The first experiment was carried out under laboratory conditions, and evaluated the effect of different extracts of bracken on the seed germination percentage of Bidens pilosa, Brachiaira decumbens, E. sonchifolia and R. crispus. The second experiment was conducted under greenhouse conditions, and evaluated the effect of soil applications of dried residues of $P$. aquilinum on the germination and initial growth of the four test weeds. The experiments were carried out in facilities of the Fitotecnia Tropical research group of the Universidad Nacional de Colombia, Medellín, Antioquia (Colombia).

\section{Study area}

The collection of soil, seeds of the four test weeds, and plant material of $P$. aquilinum were carried out in an agricultural farm located in the municipality of Marinilla, Antioquia, Colombia $\left(6^{\circ} 7^{\prime} 48^{\prime \prime} \mathrm{N} ; 75^{\circ} 23^{\prime} 24^{\prime \prime} \mathrm{W}\right)$, at 2.120 m.a.s.l., with an air temperature ranging between 18 and $24^{\circ} \mathrm{C}$ during the year, and an average annual rainfall of $2.244 \mathrm{~mm}$ (Cornare, 2012). According to the global bioclimatic scheme for the classification of terrestrial areas by Holdridge (1982), the life zone corresponds to the Premontane Humid Forest, with climates characterized as cold humid, and cold very humid. The local soil belongs to the order of the Andisols and is characterized by the presence of volcanic ash, high acidity and aluminum saturation, high organic matter, phosphorus retention, and low fertility. The relief is composed of high and low hills, terraces, and alluvial plains (IGAC, 2007). The collected soil presented a clay loam texture and an organic matter content of $28 \%$.

The greenhouse where the experiment was carried out is located in Medellin, Antioquia, Colombia $\left(6^{\circ} 15^{\prime} 47.07^{\prime \prime} \mathrm{N}\right.$; 75³4'40.02' W), at 1.520 m.a.s.l., with a temperature of 16 to $28^{\circ} \mathrm{C}$, relative humidity of 60 to $80 \%$, and $12 \mathrm{~h}$ light/12 $\mathrm{h}$ dark conditions.

\section{Collection of biological material}

Whole plants of $P$. aquilinum in the sporophytic phase, including aerial parts and of the root system, were collected by simple random sampling on a bracken population under natural infestation. The collected plants had no signs of disease, burning, or visible toxicity. The samples were dried for 24 hours at room temperature $\left(21^{\circ} \mathrm{C} \pm 2\right)$ in the dark, and subsequently in an oven at a temperature of $60^{\circ} \mathrm{C}$ for 72 hours. The dry biomass was mixed and cut into small pieces approximately $5 \mathrm{~cm}$ in length, and stored in Kraft paper at room temperature until use. At the same time, mature seeds of the weeds Bidens pilosa, Brachiaira decumbens, E. sonchifolia, and R. crispus were collected and stored in Kraft paper at $4^{\circ} \mathrm{C}$ until use.

\section{Experiment 1. Effect of extracts of $P$. aquilinum on the germination rate of the test weeds Preparation of extraxts of $P$. aquilinum}

The four organic solvents used for the extraction were hexane, dichloromethane, ethyl acetate, and methanol. All the solvents were analytical grade and purchased from MR and CIA SAS. Due to their increasing polarity, they have been commonly used in similar studies involving the extraction of metabolites (Scavo et al., 2019). The method used for the extraction was percolation (Zhang et al., 2018), and $400 \mathrm{~g}$ of dry bracken biomass were used in a funnel column packed with $500 \mathrm{~mL}$ of each of the solvents, independently. Subsequently, each sample was filtered and then concentrated by rotary evaporation (Büchi ${ }^{\circledR}, \mathrm{R}-210 \mathrm{~A}$, New York, USA) at a temperature of $45^{\circ} \mathrm{C}$ in order to remove the solvent from the solid extracts. Subsequenlty, the solid extracts were weighed and yield was estimated, reaching values of 1.0, 1.2, 1.2, and $3.7 \%$, for the extracts of hexane, dichloromethane, ethyl acetate, and methanol, respectively. For solution preparation, a $2.0 \%$ Tween-20 (common surfactant) solution was used to guarantee the maximum possible solubility of the extracts, which were diluted in distilled water to obtain a final application concentration of the $1 \% \mathrm{w} / \mathrm{v}$. The extracts were stored in amber glass flasks and refrigerated at $4^{\circ} \mathrm{C}$ until use.

\section{Application of extracts of $P$. aquilinum on the seeds of the test weeds}

The seeds were disinfected with $1 \%$ hypochlorite for $1 \mathrm{~min}$, followed by $70 \%$ ethyl alcohol for $2 \mathrm{~min}$ and three rinses with distilled water. Subsequently, they were immersed in sterilized water for $24 \mathrm{~h}$ to start the imbibition process. The germination test was carried out in $10 \mathrm{~cm}$ Petri dishes, each one arranged with a Whatman No. 1 filter paper disc, sterilized, and sprayed with $5 \mathrm{~mL}$ of the respective extract. Twenty seeds of each weed were placed in each 
Petri dish. The control treatment consisted of seeds arranged in discs sprayed with a solution of sterile distilled water and $2.0 \%$ Tween-20. The sprinkled Petri dishes were kept at room temperature $\left(21^{\circ} \mathrm{C}\right.$ \pm 2 ) under $12 \mathrm{~h} \mathrm{light} / 12 \mathrm{~h}$ dark conditions for 15 days, while seed germination was recorded as a response variable. The treatments corresponded to the extracts obtained with each of the four solvents and the respective control, applied at a concentration of $1 \% \mathrm{w} / \mathrm{v}$. For each weed species, a completely randomized experimental design was used, including the five treatments described and four replicates per treatment. The experimental unit was a Petri dish with 20 seeds.

Experiment 2. Effect of soil applications of dry residues of $P$. aquilinum on the germination and initial growth of the test weeds

Four different concentrations of dry residues of $P$. aquilinum $(0,2,5$, and $10 \%)$ were evaluated, following a proportion of $0,10,25$, and $50 \mathrm{~g}$ of dry weight per $500 \mathrm{~g}$ of soil, respectively. The dried residues were mixed with the soil and allowed to decompose naturally in plastic pots for a week before weeds sowing. The control treatment was filled with soil only (no dry residues). In each pot, 20 seeds of each weed were sown and kept under greenhouse conditions, keeping the soil at field capacity. The response variables were: germination rate, height, root length, and dry weight of the seedlings, evaluated 30 days after sowing and measured with a digital caliper (Tacklife, DC02, Bogotá, Colombia). For each weed species, a completely randomized experimental design was used, with four treatments (concentrations of 0,2 , 5 , and $10 \%$ ) and five replicates per treatment. The experimental unit was each pot with 20 seeds.

\section{Statistical analysis}

Data were tested for homoscedasticity and normality using the Levine and Shapiro-Wilk tests, respectively. Since the data did not comply with the normality assumption, they were transformed following the Box-Cox method, and the assumption of normality was evaluated again on the transformed variables. Again, the data did not comply with the assumption of normality, and were analyzed by non-parametric statistics, comparing the treatments using the Kruskal-Wallis and Wilcoxon rank tests. Values of $p<0.05$ were considered statistically significant. The analysis was carried out in the statistical and programming software R-Project ${ }^{\circledR}$ version 3.6.1 (The $\mathrm{R}$ Core Time, 2019).

Qualitative detection of some chemical groups present in extracts of $P$. aquilinum

The phytochemical characterization was based on the grouping of structurally similar metabolites in order to identify them by their chemical behavior against the addition of standardized reactions. Coloration tests were carried out for the detection of substances from the group of terpenes and terpenoids, flavonoids, tannins, and polyphenols (Marcano and Hasegawa, 1991; Lock de Ugaz, 1994). Approximately 2 g of each crude extract were diluted in $20 \mathrm{~mL}$ of ethanol at a concentration of $96 \%$ and divided into four parts. For the first chemical group, it was necessary to carry out a previous separation procedure, in which an extract in petroleum ether was obtained from the dry ethanolic extract. This ethereal extract was extracted again with a mixture of methanol-water (9:1). The upper layer was recovered and subjected to thin-layer chromatography using silica gel (TLC $60 \mathrm{~F}_{254^{\prime}}$ Merck, USA) as the stationary phase, and a mobile phase composed of a hexane-ethyl acetate mixture (95:5). The developed chromatography was allowed to dry before revealing, and sprayed with Liebermann-Burchard reagent (ethanolic solution of acetic anhydride and sulfuric acid), and subjected to heating $\left(110^{\circ} \mathrm{C}\right)$ for 5 to $10 \mathrm{~min}$. It was considered as a positive result if, under these conditions (red), blue or green shades appeared. For the detection of flavonoids, $1 \mathrm{~mL}$ of concentrated hydrochloric acid $(\mathrm{HCl})(37 \%)$ was added in $1 \mathrm{~mL}$ of each extract and it was heated in a boiling water bath for 10-15 min. The appearance of a reddish, intense yellow, or orange color under these conditions indicated the presence of flavonoids. For the detection of tannins and polyphenols, $1 \mathrm{~mL}$ of ferric chloride $\left(\mathrm{FeCl}_{3}\right)$ was added at a concentration of $10 \%$ in 1 $\mathrm{mL}$ of each extract and it was considered positive if it produced green, blue, or black colors after the addition of $\mathrm{FeCl}_{3}$ in the precipitate. All results are reported as the presence or absence of the metabolite.

\section{RESULTS}

Effect of extracts of $P$. aquilinum on the germination rate of the test weeds

The extracts of $P$. aquilinum inhibited germination of the four test weeds, varying with the solvent used and test species (Table 1). In the case of Bidens pilosa, seed germination was inhibited in all the treatments, with reductions ranging from 51.6 to $66.7 \%$, while the treatment with dichloromethane was the most efficient. On the seeds of Brachiaira decumbens, a significant response was only observed with the dichloromethane extract, which inhibited germination by $61.34 \%$. The seeds of E. sonchifolia were particularly the most sensitive to all the 
Table 1. Effect of extracts of Pteridium aquilinum on seed germination of Bidens pilosa, Brachiaria decumbens, Emilia sonchifolia, and Rumex crispus.

\begin{tabular}{|c|c|c|c|c|c|c|c|c|}
\hline \multirow[b]{2}{*}{ Treatment } & \multicolumn{2}{|c|}{ Bidens pilosa } & \multicolumn{2}{|c|}{ Brachiaria decumbens } & \multicolumn{2}{|c|}{ Emilia sonchifolia } & \multicolumn{2}{|c|}{ Rumex crispus } \\
\hline & $\begin{array}{c}\text { Germination } \\
(\%)\end{array}$ & $\begin{array}{c}\text { Inhibition } \\
(\%)\end{array}$ & $\begin{array}{c}\text { Germination } \\
(\%)\end{array}$ & $\begin{array}{c}\text { Inhibition } \\
(\%)\end{array}$ & $\begin{array}{c}\text { Germination } \\
(\%)\end{array}$ & $\begin{array}{c}\text { Inhibition } \\
(\%)\end{array}$ & $\begin{array}{c}\text { Germination } \\
(\%)\end{array}$ & $\begin{array}{c}\text { Inhibition } \\
(\%)\end{array}$ \\
\hline Control & $75 \mathrm{a}$ & NA & $38.8 \mathrm{a}$ & NA & $45 \mathrm{a}$ & NA & $80 \mathrm{a}$ & NA \\
\hline Hexane & $29 \mathrm{~b}$ & $61.6 \mathrm{~b}$ & $37.5 \mathrm{a}$ & $3.35 \mathrm{a}$ & $10 \mathrm{bc}$ & $77.8 \mathrm{bc}$ & $10 \mathrm{~cd}$ & $87.5 \mathrm{~cd}$ \\
\hline Dychloromethane & $25 b$ & $66.7 b$ & $15 \mathrm{~b}$ & $61.3 \mathrm{~b}$ & $13 \mathrm{bc}$ & $72.2 \mathrm{bc}$ & $52.5 \mathrm{a}$ & $34.4 \mathrm{a}$ \\
\hline Ethyl acetate & $26 \mathrm{~b}$ & $64.9 \mathrm{~b}$ & $37.5 \mathrm{a}$ & $3.35 \mathrm{a}$ & $1.3 \mathrm{c}$ & $97.1 \mathrm{c}$ & $20 \mathrm{bc}$ & $75 \mathrm{bc}$ \\
\hline Methanol & $36 \mathrm{~b}$ & $51.6 \mathrm{~b}$ & $32.5 \mathrm{a}$ & $16.2 \mathrm{a}$ & $3.8 \mathrm{c}$ & $91.6 \mathrm{c}$ & $7.5 \mathrm{~d}$ & $90.6 \mathrm{~d}$ \\
\hline
\end{tabular}

Values with the same letter do not differ statistically from each other according to Kruskal Wallis and Wilcolxon tests $(\mathrm{p}<0.05)$. NA= Not applicable.

extracts evaluated, being the treatments with ethyl acetate and methanol those that showed the greatest inhibitory effect on germination, with reductions of $97.11 \%$ and $91.56 \%$, respectively. On $R$. crispus, there was a significant inhibition of germination in all the treatments evaluated, except for the extract with dichloromethane. Similarly, the extracts with ethyl acetate and methanol recorded the highest inhibition of germination, reaching $87.5 \%$ and $90.6 \%$, respectively (Table 1 ).

Effect of the soil applications of dry residues of $P$. aquilinum on the germination and initial growth of the test weeds

Neutral, inhibition, and/or stimulant responses were evidenced depending on the concentration of the dry residues incorporated into the soil and the growth variable evaluated within each type of weed (Fig. 1). The inhibitory effects were more consistent on the germination variable for the four test weeds, with significant reductions resulting from the lowest concentration of $2 \%$. The germination percentage of $R$. crispus seeds decreased as the residue concentration increased, reaching a final reduction of approximately $40 \%$. E. sonchifolia was the most affected species, recording a significant reduction of $44 \%$ in germination with the application of the lowest concentration of $2 \%$. However, the higest concentration resulted in an increase in germination. For Brachiaira decumbens and Bidens pilosa, concentrations of 10 and 5\% caused the highest inhibitory response of 27 and $18 \%$, respectively (Fig. 1A). In terms of plant height, Brachiaira decumbens and E. sonchifolia recorded significant differences with respect to the control, showing inhibition and stimulant responses, respectively. In this sense, plant height of Brachiaira decumbens was reduced by an average of $22 \%$ when using any of the three concentrations of dry residues; whereas E. sonchifolia recorded a significant increase with soil applications of $5 \%$ (Fig. 1B). Regarding root length, the three concentrations applied resulted in inhibitory effects in Brachiaira decumbens, recording an average reduction of $45 \%$ compared to the control. The $10 \%$ conentation of dry residues produced negative effects on Bidens Pilosa $(-30 \%)$. On the contrary, E. sonchifolia exhibited stimulant effects, with a significant increase of approximately $40 \%$ in root length (Fig. 1C). In terms of plant dry weight, only Brachiaira decumbens recorded negative effects, with an approximate reduction of $20 \%$. Conversely, E. sonchifolia, and R. crispus exhibited stimulant effects as the concentration of the soil applications increased (Fig. 1D).

Qualitative detection of some chemical groups present in extracts of $P$. aquilinum

The phytochemical analysis showed the presence of three functional chemical groups in the extracts of $P$. aquilinum: flavonoids, tannins, and polyphenols. The flavonoids were present in the extractions with ethyl acetate, while tannins and polyphenols were found in methanolic extracts. In the extracts with dichloromethane and hexane, the presence of any of the chemical groups included in this study was not detected (Table 2).

\section{DISCUSSION}

Effect of extracts of $P$. aquilinum on the germination rate of the test weeds

The inhibitory effect of $P$. aquilinum extracts on the germination of the four weeds was influenced by the type of recipient species and the solvent involved, which confirms the wide diversity of biological responses that can occur in plant-plant allelopathy. Starting from the plant component, the sensitivity of the species to the extracts was represented from highest to lowest by $E$. sonchifolia $>R$. crispus $>$ Bidens pilosa $>$ Brachiaria decumbens $>$ E. sonchifolia, with germination inhibition percentages higher than $70 \%$ in all the 


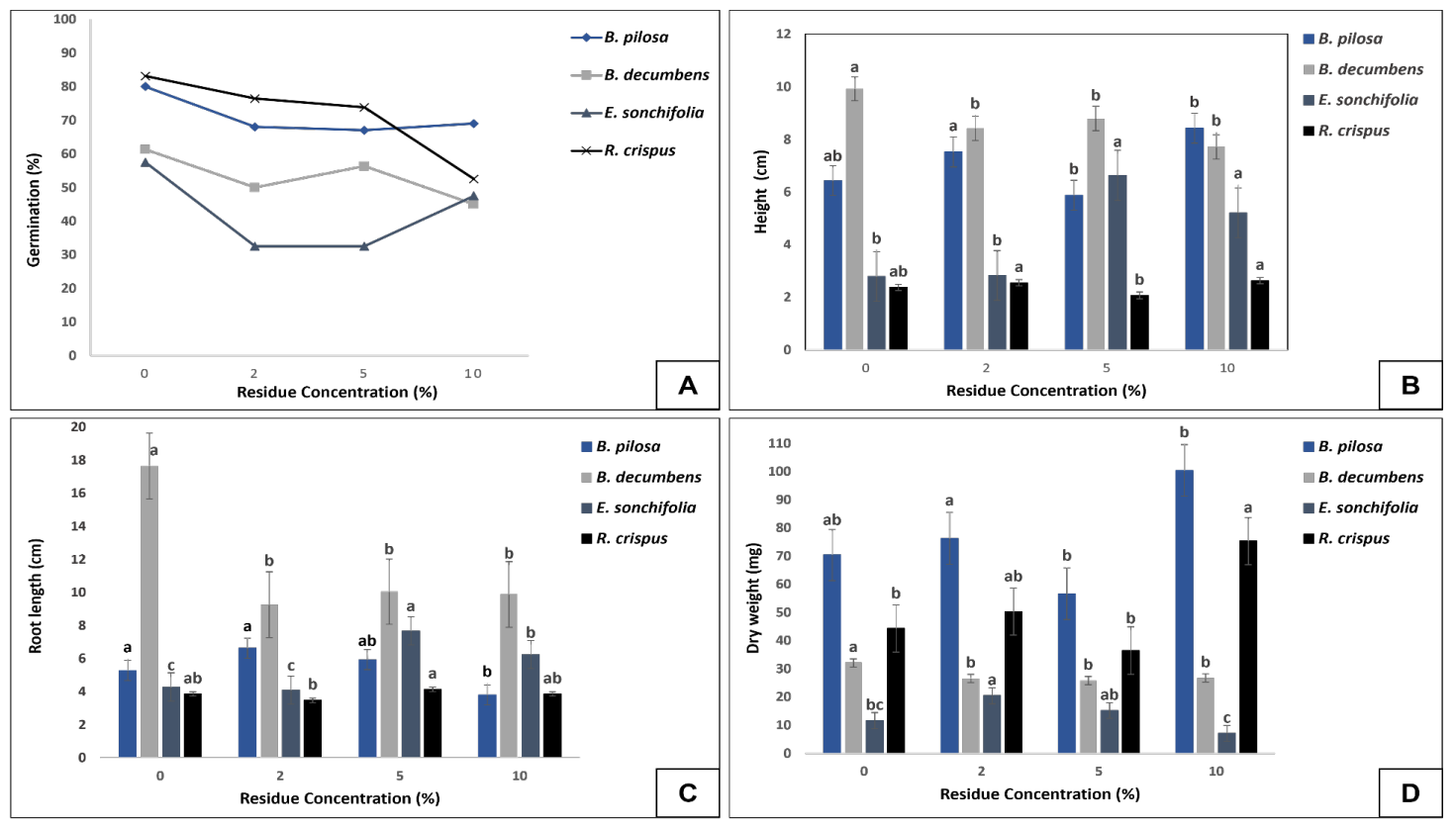

Fig. 1. Effect of soil application of four concentrations of dry residues of $P$. aquilinum on the germination and initial growth of Bidens pilosa, Brachiaria decumbens, Emilia sonchifolia and Rumex crispus. A. Effects on the germination rate. B. Effects on weed height $C$. Effects on weed root length. D. Effects on dry weight of weeds. Values with the same letter do not differ statistically from each other according to the Kruskal Wallis and Wilcolxon tests $(p<0.05)$.

Table 2. Phytochemical results of the groups present or absent in the extracts of P. aquilinum under four different solvents.

\begin{tabular}{lccccc}
\hline & & \multicolumn{4}{c}{ Result in extracts (*) } \\
\cline { 3 - 6 } Substance & Test used & Hexane & Dichloromethane & Ethyl acetate & Methanol \\
\hline Terpenes and & Liebermann- & - & - & - & - \\
terpenoids & Burchard & & - & + & - \\
Flavonoids & $\mathrm{HCl}$ & - & - & - & + \\
Tannins & $\mathrm{FeCl}_{3}$ & - & - & - & + \\
Polyphenols & $\mathrm{FeCl}_{3}$ & - & - &
\end{tabular}

* $(+)$ = Presence; $(-)=$ Absence.

treatments. This result is considered promising for $P$. aquilinum since a $32 \%$ reduction in germination was reported when applying aqueous foliar extracts of Leucaena leucocephala (Lam.) (Ishak et al., 2016). On the other hand, Brachiaria decumbens presented the lowest sensitivity to the extracts, with germination rates similar to the control in three of the four solvents evaluated. In terms of seed allelopathy, Brachiaria sp., contains important sources of phytochemical compounds that can compromise the germination processes involved (Rodrigues et al., 2012). Furthermore, several species of this genus have been reported to have the ability to negatively affect the growth of various weeds and other cultivated plants through biochemical interactions (Krause et al., 2020). A study on Bidens pilosa revelealed that the seeds are especially sensitive to aqueous extracts of Baccharis spp. (Dias, et al., 2017) and Conyza sumatrensis (Retz.) E. Walker (Ferreira et al., 2020), which reduced germination up to $80 \%$. However, it is important to note that those results were obtained when using $10 \%$ concentrations, while similar results were obtained with the extract of $P$. aquilinum at $1 \%$ in the present study. For $R$. crispus, inhibition of seed germination by 
aqueous extracts of four different plants (Oryza sativa L., Parthenium hysterophorus L., Phragmites australis Cav., and Datura alba L.) averaged 50\% (Afridi and Khan, 2015) and $52.2 \%$ by ethanolic extracts of Furcraea macrophylla Baker and Cyperus rotundus L. (Osorio et al., 2009). This study showed a $67 \%$ germination inhibition of this species when using extracts of $P$. aquilinum in dichloromethane.

Regarding the type of solvent used, the effect on the recipient population is influenced by the type of metabolite incorporated in each solution, according to its composition and chemical nature. For example, the inhibitory effect on the germination and growth of Poa pratensis L. seedlings was attributed to the presence of pterosin $\mathrm{B}$ and pterosin $\mathrm{F}$ in the ethanolic extracts of $P$. aquilinum (Butnariu et al., 2015). In our study, the extract with dichloromethane presented the highest inhibitory results in the germination of Bidens pilosa and Brachiaria decumbens, which shows the sensitivity of these seeds to compounds of low polarity. In bioassays with extracts of Lippia alba L., a greater inhibitory response was also observed in lettuce and onion when using extracts in the dichloromethane fraction, compared to the other tested solvents (Texeira et al., 2019). On the other hand, the seeds of E. sonchifolia and R. crispus showed greater sensitivity to the compounds of $P$. aquilinum present in the methanol extract, which was the solvent with the highest polarity in this study, being able to dissolve chemical substances soluble in water that were phytotoxic for such species. Scavo et al. (2019) have mentioned that the differences presented in the degrees of sensitivity of the recipient plants are often related to factors such as the type of absorption mechanism, translocation, and active site of the allelopathic compounds. However, different responses in the same plant depend on conditions such as concentration, development stage and environmental conditions (Scavo et al., 2019). Our results suggest that the extracts of $P$. aquilinum have an interesting role in reducing germination of the four weeds under study, including species of the class Liliopsida (Brachiaira decumbens) and Magnoliopsida (Bidens pilosa, E. sonchifolia, R. crispus), with an average inhibition of $60 \%$. A similar study conducted by Scavo et al. (2018) reported an average reduction of $41 \%$ in the germination of Amaranthus retroflexus L., Diplotaxis erucoides (L.) DC., and Portulaca oleracea L. when using aqueous extracts of Cynara cardunculus L. Likewise, Scavo et al. (2020) similar results to those of our study, reporting that all the extracts of C. cardunculus evaluated (water, ethanol, and methanol) showed inhibitory effects on the germination of weed seeds of Magnoliopsida ( $A$. retroflexus, P. oleracea, Anagallis arvensis L.) and Liliopsida classes (Stellaria media (L.) Vill). This fact is interesting for the IWMS objectives since it suggests that the possible use of such compounds would have a greater range of action by exerting negative effects on weeds of different botanical families and even classes.

\section{Effect of soil applications of dry residues of $P$. aquilinum on the germination and initial growth of the test weeds}

The results of our study suggests that the incorporation of dry $P$. aquilinum residues into the soil mainly exerts negative effects on the four test weeds, but a stimulant-response was also evidenced in some cases. According to Kumar et al. (2018), allelopathic interactions include both inhibition and stimulant responses, which are generally associated with the dose and/or concentration used. For example, Ismail et al., (2015) found that the dry residues of Pennisetum purpureum Schumach incorporated into the soil at a concentration of $5 \%$, inhibited dry weight, fresh weight, root length, and shoot length of Eleusine indica (L.) Gaertn. However, when using a $1 \%$ dose, stimulant effects were observed on the same variables. This suggests that the type of allelochemicals present during the decomposition of bracken biomass mainly exert their activity on the physiological processes that occur during germination of the studied seeds, being less substantial during other growth and development processes. This finding might suggest a possible pre-emergence activity, which could reduce the establishment of such weeds from the initial stages of germination.

The fact that the residues reduced germination but stimulated the dry weight of E. sonchifolia and $R$. crispus shows that phytotoxicity of these metabolites was also short-lived and that their effect was gradually reduced with time as it often happens in this type of biochemical interactions (Xuan et al., 2003). It should be noted that the positive effects of allelopathy in weed management include the total or partial inhibition of germination as well as a delay in it, with which the crops obtain a competitive advantage in their initial growth (Runzika et al., 2013). On the other hand, it is possible that the increase in dry weight observed in these two species is related to the increase in the concentration of the dry residues applied, and thus the content of nitrogen and/ or organic matter contributed (De Moraes et al., 2017).

The reductions of 30 and $82 \%$ in root length found in Bidens pilosa and Brachiaria decumbens, respectively, represents a promising finding from the point of view of the competitive reduction of 
these plants, since both weeds present a dense, vigorous, and well-developed root system, which allows a great capture of resources, reproduction, and survival (Dragomir et al., 2017). According to Turk and Tawaha (2003), allelochemicals are mainly soluble in water, and roots generally absorb allelochemicals from the humid environment due to their direct contact with them, which often makes them more affected by different concentrations compared to other organs such as seedling shoots. Oraon and Mondal (2021) reported similar results in rice and found that root length was more affected by the allelopathic activity of Hyptis suaveolens (L.) Poit., and Leucas cephalotes (Roth) Spren than other growth parameters. In addition, a study conducted by Jatoba et al. (2016) identified the proanthocyanidin selligueain $\mathrm{A}$ as the main secondary compound present in the green leaves and litter of bracken Pteridium arachnoideum (Kaulf.) Maxon, and responsible for inhibiting root length and size of the metaxylem cells of Sesamum indicum L. Furthermore, the authors reported that the allelochemical was also present in the soil solution.

The literature has described that the interaction of the allelochemical in the soil plays a crucial role in the biological response due to the multiple interactions and/or transformations that the active substances can undergo (Scavo et al., 2019). Therefore, the effects exhibited during this methodology may be conditioned to such interactions, until now unknown. Although the soil used during the experiments was obtained directly from the life zone of the population under study, it is evident that different environmental conditions intervene: e.g., temperature, humidity, light intensity, added to the effects of biota and the physicochemical structure of the soil in allelopathic processes (Reigosa et al., 2013).

\section{Qualitative detection of some chemical groups present in extracts of $P$. aquilinum}

The flavonoids, tannins, and polyphenols present in the extracts of $P$. aquilinum in this experiment are associated with the sensitivity of the seeds of Bidens pilosa, E. sonchifolia, and R. crispus. According to Marchiosi et al. (2020), phenolic compounds, such as flavonoids and tannins, are commonly the class of secondary metabolites that allelopathic activities are most associated with. Regarding the activity of these compounds, other studies have reported that the inhibitory effects caused by tannins are related to their ability to bind to different molecules and/ or precipitate proteins and to the reduction in the synthesis of hydrolytic enzymes (Issaoui et al.,
2020); whereas some flavonoids seem to interfere with the functional or structural organization of the chloroplast, also inhibiting the absorption of minerals and the production of ATP in the mitochondria (Marchiosi et al., 2020). Polyphenols are described as compounds responsible for causing damage to the roots of susceptible plants (Hsueh et al., 2020). These reports could contribute to the understanding of possible modes of action of $P$. aquilinum compounds on the test species. However, confirmation of such processes is beyond the scope of our research.

Compounds such as tannins, phenolic acids (ferulic, $p$-coumaric, vanillic), and coumarins have been described as responsible for inhibiting the action of gibberellin in germination by producing precipitation of hydrolases ( $\alpha$-amylase), responsible for the degradation of starch and sugars during this process (Saleh et al., 2015). Furthermore, coumarins can block the sites of action of gibberellins ( $\mathrm{Li}$ and Gao, 2011). As mentioned above, Leitolis et al. (2017) reported the presence of $p$-coumaric acid in $P$. aquilinum, which could largely explain the inhibitory effects on germination observed in our two experiments.

Finally, although there was no direct isolation or detection of the allelochemicals present in the extracts of $P$. aquilinum in the present study, the results showed that there could be other chemical groups, other than those analyzed here, responsible for the inhibition of germination in Brachiaria decumbens since the dichloromethane extract did not show the presence of these. However, the active principles associated with this effect are unknown for the scope of this study.

\section{CONCLUSIONS}

$P$. aquilinum exerts inhibitory effects on the germination of Bidens pilosa L., Brachiaria decumbens Stapf, Emilia sonchifolia (L.) DC. ex DC and Rumex crispus L. The extract resulted in higher inhibition in E. sonchifolia, while Brachiaria decumbens was the most sensitive specied to dry residues of bracken. The presence of flavonoids, tannins, and polyphenols present in the methanol and ethyl acetate extracts is associated with the inhibitory effect on the germination of Bidens pilosa, E. sonchifolia, and R. crispus.

\section{ACKNOWLEDGMENT}

We thank people from Fitotecnia Tropical research group and Politécnico Colombiano Jaime Isaza Cadavid for financing this project. 


\section{LITERATURE CITED}

Afridi, R., and M. Khan. 2015. Comparative effect of water extract of Parthenium hysterophorus, Datura alba, Phragmites australis, and Oryza sativa on weeds and wheat. Sains Malaysiana 44(5):693-699. Doi: 10.17576 / jsm-2015-440508.

Bardon, C., B. Misery, F. Piola, F. Poly, and X. LeRoux. 2018. Control of soil N cycle processes by Pteridium aquilinum and Erica cinerea in heathlands along a $\mathrm{pH}$ gradient. Ecosphere 9(9):24-26. Doi: 10.1002/ecs2.2426

Bracho, B., y O. Arnaude. 2012. Efecto de extractos acuosos de Pteridium aquilinum L. Kuhn var. caudatum sobre el crecimiento de plántulas de Solanum lycopersicum L. Agronomía Tropical 62(1-4):39-50.

Butnariu, M., I. Samfira, I. Sarac, A. Negrea, and P. Negrea. 2015. Allelopathic effects of Pteridium aquilinum alcoholic extract on seed germination and seedling growth of $\mathrm{Poa}$ pratensis. Allelopathy Journal 35(2):227-236.

Chauhan, B., H. Hafiz, and S. Florentine. 2019. Seed germination ecology of Bidens pilosa and its implications for weed management. Scientific Reports 9(1):1-9. Doi: 10.1038/ s41598-019-52620-9.

Cheng, F., and Z. Cheng. 2015. Research progress on the use of plant allelopathy in agriculture and the physiological and ecological mechanisms of allelopathy. Frontiers in Plant Science 6:10-20. Doi: 10.3389/fpls.2015.01020.

Cornare. 2012. Evaluación y zonificación de riesgos por avenida torrencial, inundación y movimiento en masa y dimensionamiento de procesos erosivos en el municipio de Marinilla. Ministerio de Medio Ambiente y Desarrollo Sostenible. Gobernación de Antioquia, Colombia. Doi: 10.1017/ CBO9781107415324.004.

De Moraes, M., D. Bertoncelli, G. Cito, and G. Freiria. 2017. Allelopathic potential of the aqueous extract of Raphanus sativus L., on the germination of beans and corn seeds. Open Access Library Journal 04(05):1-10. Doi: 10.4236/oalib.1103590.

Dias, M., R. Nozari, and E. Santarem. 2017. Herbicidal activity of natural compounds from Baccharis spp. on the germination and seedlings growth of Lactuca sativa and Bidens pilosa. Allelopathy Journal 42(1):21-36. Doi: 10.26651/2017-42-1-1103.
Dragomir, N., M. Horablaga, D. Camen, C. Dragomir, D. Rechițean, and M. Dragos. 2017. Allelopathic aspects in Rumex crispus L. and Rumex obtusifolius L. I. Allelopathic effect on grassland grasses. Romanian Journal of Grassland and Forage Crops, 5, 31-37 ref.1. http://www.ropaj.org

Eichenberg, D., C. Ristok., W. Kröber, and H. Bruelheide. 2014. Plant polyphenols implications of different sampling, storage, and sample processing in biodiversityecosystem functioning experiments. Chemistry and Ecology 30(7):676-692. Doi: 10.1080/02757540.2014.894987.

Ferreira, P., P. Zonetti, A. Albrecht, I. Rosset, A. Silva, L. Albrecht, A. Vieira, R.Paulert. 2020. Conyza sumatrensis allelopathy effect on Bidens pilosa (Asteraceae) seed germination. Botanical Sciences 98(2):348-354. Doi: 10.17129/botsci.2445.

Gil, R., M. Bastos, P. Oliveira, and C. Lopes. 2012. Bracken-associated human and animal health hazards: Chemical, biological and pathological evidence. Journal of Hazardous Materials Elsevier B.V 203:1-12. Doi: 10.1016/j.jhazmat.2011.12.046.

Grace, E., T. Sunday, and U. Ikemesit. 2020. In vitro antioxidant analysis and quantitative determination of phenolic and flavonoid contents of Emilia sonchifolia (L) D.C (Asteraceae) leaf extract and fractions. GSC Biological and Pharmaceutical Sciences, 11(2):044-052. Doi: 10.30574/ gscbps.2020.11.2.0123.

Heap. 2021. International Survey of Herbicide Resistant Weeds. Herbicide Resistance Action Committee, North American Herbicide Resistance Action Committee, and the Weed Science Society of America. Available at: www.weedscience.org

Holdridge, L. R. 1982. Ecología basada en zonas de vida. 1a ed. Instituto ínteramericano de cooperación para la agricultura (IICA), San José, Costa Rica. Doi: 10.1017/ CBO9781107415324.004.

Hujerová, R., L. Pavlů, V. Pavlů, M. Hejcman, and J. Gaisler. 2017. Dynamics of above-ground and below-ground biomass of Rumex crispus, Rumex obtusifolius, and the new weedy species Rumex hybrid cv. OK-2 (R. patientia $x R$. tianschanicus) in the seeding year. Weed Research 57(2):81-90. Doi: 10.1111/wre.12240.

Hsueh, M., C. Fan, and W. Chang. 2020. Allelopathic Effects of Bidens pilosa L. var. radiata Sch. Bip. on the tuber sprouting and seedling growth of Cyperus rotundus L. Plants 9(6):742. Doi: 10.3390/plants9060742. 
Ishak, M., B. Ismail, and N. Yusoff. 2016. Allelopathic potential of Leucaena leucocephala (Lam.) on the germination and seedling growth of Ageratum conyzoides L., Tridax procumbens L., and Emilia sonchifolia (L.) DC. Allelopathy Journal 37(1):109-122. Doi: 0971-4693/94

Ismail, B., P. Tan, and T. Chuah. 2015. Assessment of the potential allelopathic effects of Pennisetum purpureum Schumach., on the germination and growth of Eleusine indica (L.) Gaertn. Sains Malaysiana, 44(2):269-274. Doi: 10.17576 / jsm-2015-4402-15

IGAC. 2007. Estudio general de suelos y zonificación de tierras en el Departamento de Antioquia. Instituto Geográfico Agustín Codazzi, Bogotá, Colombia.

Issaoui, H., F. Charrier, and E. Bouhtoury. 2020. Bio-based products from wood materials. In Galanakis C. (Ed.), Biobased Products and Industries (p. 245-277). Doi: 10.1016/B978-012-818493-6.00007-5.

Jatoba, L., R. Varela, J. Maria, and G. Molinillo. 2016. Allelopathy of bracken fern (Pteridium arachnoideum): New evidence from green fronds, litter, and soil. PLoS ONE, 11(8), 1-16. Doi: 10.1371/journal.pone.0161670.

Krause, M., L. Merlo, C. Merlo, H. Nei, and M. Ferrerira. 2020. Effect of aqueous extracts of Brachiaria decumbens on the development of ornamental pepper. Agronomia Colombiana 38(1):53-60. Doi: 10.15446/agron.colomb. v38n1.79443.

Kumar, V., N. Aggarwal., and K. Njali. 2018. Bioherbicidal Concept: A Novel Strategy to Control Weeds, in Singh, J. et al. (eds) Microbial Bioprospecting for Sustainable Development. Springer, Singapore. 29-40. Doi: 10.1007/978-981-13-0053-0_2.

Leitolis, A., F. DeSouza, K. Freitas, H. Barddal, L. Rauh, J. Franco, and L. Pereira. 2017. Tissue damage and embryonic malformation induced by aqueous extract of Pteridium aquilinum on chorioallantoic membrane of chick embryo (CAM). Semina: Ciencias Agrarias 38(3), 1451-1460. Doi: 10.5433/1679-0359.2017v38n3p1451

Li, J., L. Chen, Q. Chen, Y. Miao, Z. Peng, B. Huang, L. Guo, D. Liu, and H. Du. 2021. Allelopathic effect of Artemisia argyi on the germination and growth of various weeds. Scientific Reports, 11(1):1-15. Doi: 10.1038/ s41598-021-83752-6

Lock de Ugaz, O. 1994. Investigación fitoquímica: Métodos en el estudio de productos naturales. $2^{\circ}$ ed. Fondo Editorial Pontificia Universidad Católica del Perú.
Lovatto, B., C. Mauch, E. Lobo, and G. Schiedeck. 2016. Evaluation of Pteridium aquilinum (Dennstaedtiaceae) and Urtica dioica (Urticaceae) as alternatives to populational aphid balance in organic crops in southern Brazil. Revista de la Facultad de Agronomia (La Plata) 115(2):265-271.

Macías, F., F. Mejías, and J. Molinillo. 2019. Recent advances in allelopathy for weed control: from knowledge to applications. Pest Management Science, 75(9):2413-2436. Doi: $10.1002 /$ ps.5355

Marcano, D., and M. Hasegawa. 1991. Fitoquímica orgánica. Universidad Central de Venezuela. Consejo de desarrollo científico y humanístico.

Marchiosi, R., D. Wanderley, R. Polimeni, R. Barbosa, A. Soares, A. Finger-Teixeira, et al... 2020. Biosynthesis and metabolic actions of simple phenolic acids in plants. Phytochemistry Reviews. Doi: 10.1007/ s11101-020-09689-2.

Oliveira, S., A. Silva, E. Alves, A. Ferreira, and L. Galon. 2015. Chapter 7 - Weed Management. In Santos, F., A. Borém, and C. Caldas (Eds.), Sugarcane: Agricultural Production, Bioenergy and Ethanol (pp. 133-159). Academic Press. Doi: 1016/B978-0-12-8022399.00007-4

Oraon, S., and S. Mondai. (2021). Allelopathic Effect of Lamiaceous Weeds on Seed Germination and Early Growth of Aromatic Rice (Oryza sativa 'Gobindobhog'). Acta Agrobotanica, 74: 1-10. Doi: 10.5586/aa.741

Osorio, L., F. Valverde, C. Bonilla, M. Sánchez, and C. Mier. 2009. Evaluación de extractos de fique, coquito, sorgo y ruda como posibles bioherbicidas. Acta Agronomica 58(2):103108.

Reigosa, M., A. Gomes, A. Ferreira, and F. Borguetti. 2013. Allelopathic research in Brazil. Acta Botanica Brasilica 27(4):629-646. Doi: 10.1590/S0102-33062013000400001.

Rice, E. 1984. Allelopathy. 2nd Ed. Orlando, USA: Academic Press.

Riley, P., Cotter, J. Contiero, and M. Watts. 2011. Tolerancia a herbicidas y cultivos transgénicos, greeanpeace international. Edited by B. Price and M. Pispin. Available at: http://www.greenpeace.org/argentina/ Global/argentina/report/2011/bosques/ informe-glifosato-español-v2.pdf.

Rodrigues, A., L. Valdemir, S. Pereira, and C. Deiss. 2012. Allelopathy of two Brachiaria species in seeds of three species of stylosanthes. Ciencia rural. 42(10):1758-1763. Doi: 10.1590/S0103-84782012001000007 
Runzika, M., J. Rugare, and S. Mabasa. 2013. Screening green manure cover crops for their allelopathic effects on some important weeds found in zimbabwe. Asian Journal of Agriculture and Rural Development3(9):667673. Doi: 10.22004/AG.ECON.198234.

Saleh, A., M. Madany, and L. González. 2015. The effect of coumarin application on early growth and some physiological parameters in faba bean (Vicia faba L.). Journal of Plant Growth Regulation 34(2):233-241. Doi: 10.1007/s00344-014-9459-4.

Scavo, A., A. Restuccia, G. Pandino, A. Onofri, and G. Mauromicale. 2018. Allelopathic effects of Cynara cardunculus L., leaf aqueous extracts on seed germination of some Mediterranean weed species. Italian Journal of Agronomy, 13(2):119-125. Doi: 10.4081/ija.2018.1021

Scavo, A., C. Abbate, and G. Mauromicale. 2019. Plant allelochemicals: agronomic, nutritional, and ecological relevance in the soil system. Plant and Soil 442(1-2):23-48. Doi: 10.1007/ s11104-019-04190-y

Scavo, A., and G. Mauromicale. 2020. Integrated weed management in herbaceous field crops. Agronomy, 10(4):66. Doi: 10.3390/ agronomy10040466

Scavo, A., G. Pandino, A. Restuccia and G. Mauromicale. 2020. Leaf extracts of cultivated cardoon as a potential bioherbicide. Scientia Horticulturae, 261(2):109024. https://doi. org/10.1016/j.scienta.2019.109024

Ssali, F., S. Moe, and D. Sheil. 2019. The differential effects of bracken (Pteridium aquilinum (L.) Kuhn) on germination and seedling performance of tree species in the African tropics. Plant Ecology 220:41-55. Doi: 10.1007/s11258-018-0901-8.
Texeira, G., P. Avelar, J. Siquiera, and L. Rodrigues. 2019. Allelopathic effect of the ethanol extract and fractions of the aerial parts of Lippia alba (Verbenaceae). Natural Product Research 33(16):2402-2407. Doi: 10.1080/14786419.2018.1443090.

The R Core Team 2019. R: A language and environment for statistical computing. $\mathrm{R}$ Foundation for Statistical Computing. Vienna, Austria. Available at: http://www.rproject.org. (Accessed 21 March 2019).

Trezzi, M., R. Vidal, A. Balbidot, H. Bittencourt, and A. Pedro. 2016. Allelopathy: driving mechanisms governing its activity in agriculture. Journal of Plant Interactions 11(1):53-60. Doi: 10.1080/17429145.2016.1159342.

Turk, M., and A. Tawaha. 2003. Allelopathic effect of black mustard (Brassica nigra L.) on germination and growth of wild oat (Avena fatua L.). Crop Protection, 22(4):673-677. Doi: 10.1016/S0261-2194(02)00241-7

Wang, H.H., B. Chen, L. Hsu, Y. Cheng, Y. Liou, and C. Wang. 2011. Allelopathic effects of bracken fern (Pteridium aquilinum L. Kuhn) in Taiwan. Allelopathy Journal 27(11):97-110.

Xuan, T.D., E. Tsuzuki, H. Terao, M. Matsuo, T. Khanh, S. Murayama, and N. Hong. 2003. Alfalfa, rice by-products and their incorporation for weed control in rice. Weed Biology and Management 3(2):137-144. Doi: 10.1046/j.1445-6664.2003.00095.x

Zhang, Q., Lin, L., \& Ye, W. (2018). Techniques for extraction and isolation of natural products: A comprehensive review. Chinese Medicine (United Kingdom), 13(1), 1-26. https://doi. org/10.1186/s13020-018-0177-x 